\title{
Historical-Geographical View of Rural Village Gnjili Potok - Which Road to Renewal and Development
}

\author{
Goran Rajović ${ }^{1, a}$, Jelisavka Bulatović $2, b$ \\ ${ }^{1}$ Street Vojvode Stepe 252, Belgrade, Serbia \\ Phone: 0038161/19-24-850 \\ 2Department of Technology and Management, College of Textile Design, \\ Street Starine Novaka 24, Belgrade, Serbia \\ Phone: 003861/ 3082651 \\ a,bE-mail address: dkgoran.rajovic@gmail.com , jelisavka.bulatovic@gmail.com
}

\begin{abstract}
Through this work, who examines rural village Gnjili Potok points out the importance of the historical and geographical components, as well as essential guidelines to preserve the identity and authenticity of the village? Villages are still the only places where it is possible to agriculture as a life interest, but there are fewer of those who live from it. Agriculture the other activity that is linked to be village and rural area, but there is less activity that ensures the development and future of this area. Experience of the EU shows that designed rural development policy, supported financially, resulting in a successful rural economy, with employment opportunities. In Montenegro, unfortunately, until now there was no consistent and long-term rural development policy. Namely, Montenegro is a big deal to all their strategies complies with international and European principles, and planned actions and activities, with the priority ranking, to enable the realization of the vision of rural development and its competitive participation in the global and European trends.
\end{abstract}

Keywords: Gnjili Potok; settling; rural development

\section{INTRODUCTION}

Historical development of settlements, especially villages in Montenegro and their typology is not fully explored. Were carried out partial research or published general studies that are based more on in-depth research of historical material, and targeted syntheses archaeological excavations that exclusively focused on the exploration of the history of the village, and field research was partially and often only relate to the study of individual objects, rather than the entire morphology of the Montenegrin villages. "It certainly has its causes in the socialist ideology after the Second World War, which was directed towards the formation of a society in which the working class to run society, farmer is also treated like worker and a desire to be his way of life as close to the way of life of workers, led to the complete devastation of villages that have emerged in the eighteenth and 19th century as a rounded and sustainable economic system that catered to the city's community" [1].

When it comes to the lack of literature, as well as the fact that up to fifteen years ago there was not is a comprehensive text that is treated from the standpoint of any scientific discipline, 
Gnjili Potok. Just 1995 and 1999 appeared the first information views. It is a book Rajović [23] "Gnjili Potok and Trešnjevik" and "Weather and People". Above mentioned books are gives historical - sociological view Gnjili Potok and constitute a modest contribution to the understanding of these issues, so we as such during our research we used. Further, studies of rural villages Gnjili Potok, continue the authors of this text, both at the level of the village and at the level of the local community of the Kralje and as a result of the resulting texts: "Rural village Gnjili Potok as a reflection of the socio-economic conditions" [4], "Destinations freshwater fishing, Rajova River harsh and beautiful" [5], "Tourist Potential on Example of Rural Settlement Gnjili Potok (Montenegro)" [6]," Geographical starting points the analysis of current rural problems in Montenegro: A case study of the rural settlement of Gnjili Potok" [7], "Rural village Gnjili Potok - road sign towards happiness and freedom (Some geographical aspects of sustainable development)" [8], "Some Economic -Geographical Factors Development: The Case of Local Communities Kralje" [9], "Geographic Favor of Analyzing Rural Space: The Case Rural Local Communities Kralje" [10], Geographical Starting Points The Analysis Of Current Rural Problems In Montenegro: Case Study Of Rural Local Community Kralje" [11], monograph "Natural and socio economic characteristics of rural villages Gnjili Potok" [12].

Study of the whole range of issues and problems related to rural village Gnjili Potok is still pending. The results that we have announced in this study represent a modest contribution to the study of rural settlements in Montenegro. On this occasion emphasize that we have no intention, and no professional opportunities, to exhaust this issue, but on the contrary, we want to incite, further studies Montenegrin village. Thereby affirm clearly formulated opinions Avramović [13] and Isić [14], that the rural society, "a society for themselves," and "a society that has lived its life." Farmer as the backbone of rural society, mostly still, in most of cases of conservative, tends to "live the way and there as anywhere used, and how his old lived, especially the difficult quarters to other occupations. Most often it is very traditionally tied to the land, to their property and house.

\section{RESEARCH METHODOLOGY}

This research aims to provide a historical and geographical view of rural village Gnjili Potok, i.e. which way to get to the reconstruction and development. Objective of this study it was possible to realize the combined use of different research methods. The core methodological procedure used in this study does, geographic (spatial) method, whose scope of research the relating to rural village Gnjili Potok. It is in fact a geographical entity, which belongs to the municipality Andrijevica (Montenegro) and extends to between 42 $44^{\prime} 43^{\prime \prime}$ northern latitude width and $19^{\circ} 43^{\prime} 04^{\prime \prime}$ of eastern longitude. Takes up surface area of $8.83 \mathrm{~km}^{2}$ and in this area, according to survey data Rajović (2009) for 2008 year resides, i.e. permanently live 81 inhabitants. Geography settlements explore human settlements with descriptive and perspective aspect. Descriptive aspect includes a description, classification, systematization and generalization of scientific discovery unknown or partially known properties of settlements (determining legality which prevailing in development and distribution of settlements). Perspective aspect includes application of geographical knowledge on settlements in various areas of social life in order to improve the quality of life and working people. Among the most important approaches to the geography of the settlement include: descriptive mechanical approach which refers to the totality of descriptions settlements or some of its segments without considering the cause - effect relationship. Complex geographical access includes interactional 
consideration of complex territorial settlement - the environment and vice versa, from all aspects. A pragmatic approach is related to the usefulness of geographic knowledge of human settlements and their practical value. Its place in the research I found a multi-disciplinary approach, that is, the results of other disciplines on settlements [15-19]. Data source for that the related to the analysis of the population, we used the statistical method, i.e. used the data of the Office of Statistics Montenegro [20], as well as survey data Rajović [4]. Were studied and written sources on the Internet. Geographic research in this paper is based on methods: description and classification. Procedure description method, we started from a simple description of facts, processes and objects, as well as their proving empirical relationships and connections. Classification method enabled us to systematic and complete separation of the general terms on the special, which includes the concept. The method of systematization and generalization implied is cognitive processes of abstraction [20-22]. The method of analysis was related to study and explanation of reality partition of complex thought creation on their simple components. The method of synthesis, we tried to analyze the characteristics and principles of rural settlements in intervals of cause and effect link [23-29].

\section{ANALYSIS AND DISCUSSION}

Throughout the history of rural society evolved of the primitive village community to the modern, highly developed, rural society. By the first half of the 20th century peasantry in Europe was the largest and most important category of society. Different geographical, climatic, economic, historical and other factors have created significant differences, both in Europe as well as in Montenegro [30].

According to Đorđević [31] in a study of the historical component of the settlement, should start from the evolution of the village. Rajović [2] points out that the oldest traces of life in today's village Gnjili Potok originate from times of the Illyrians. More or less their traces held in the name of certain locations: Banjišor, Bulac, Gropa, Gvozda, Macurski put, Dukovka, Pridor, Tatarka, Krkline, Zaoglina, Latinski krš, Rutinka, Perinka, Njive Đinovića. According to the same author, it is almost certain that the Illyrians practiced agriculture and animal husbandry, but due to the extremely cold and huge snow migrated to warmer regions. As evidence, the presence of Illyrians Rajović [3] says that they "leave their own graves and to the present locality "Latin rubble".

On the immediate locality Orničice "beneath the asphalt road, you can see are two graves ingrown in the weeds and combination of wire of beech. Other graves are covered with an embankment of the road, which was cut by the Site and other deep in the earth. The term "Latin rubble" speaks to a Latin graveyard, probably Romanized Illyrians, and perhaps the ancient Greeks". Yes are indeed Illyrians lived in the territory of rural settlements Gnjili Potok, Rajović [2] states that "the presence of a bunch at an altitude greater than $1100 \mathrm{~m}$. It is piled up stones with a diameter of $4 \mathrm{~m}$ or more. Less is smaller and more of course. Some of piled stones are almost overgrown, and many forestages covered. Mainly are occur from localities: Latinsko cemetery, over Krklina, Radmilice, Rudog Brijega, Pridora, Korita, Katuništa to Radmilice, which areas are associated presence of old people. 


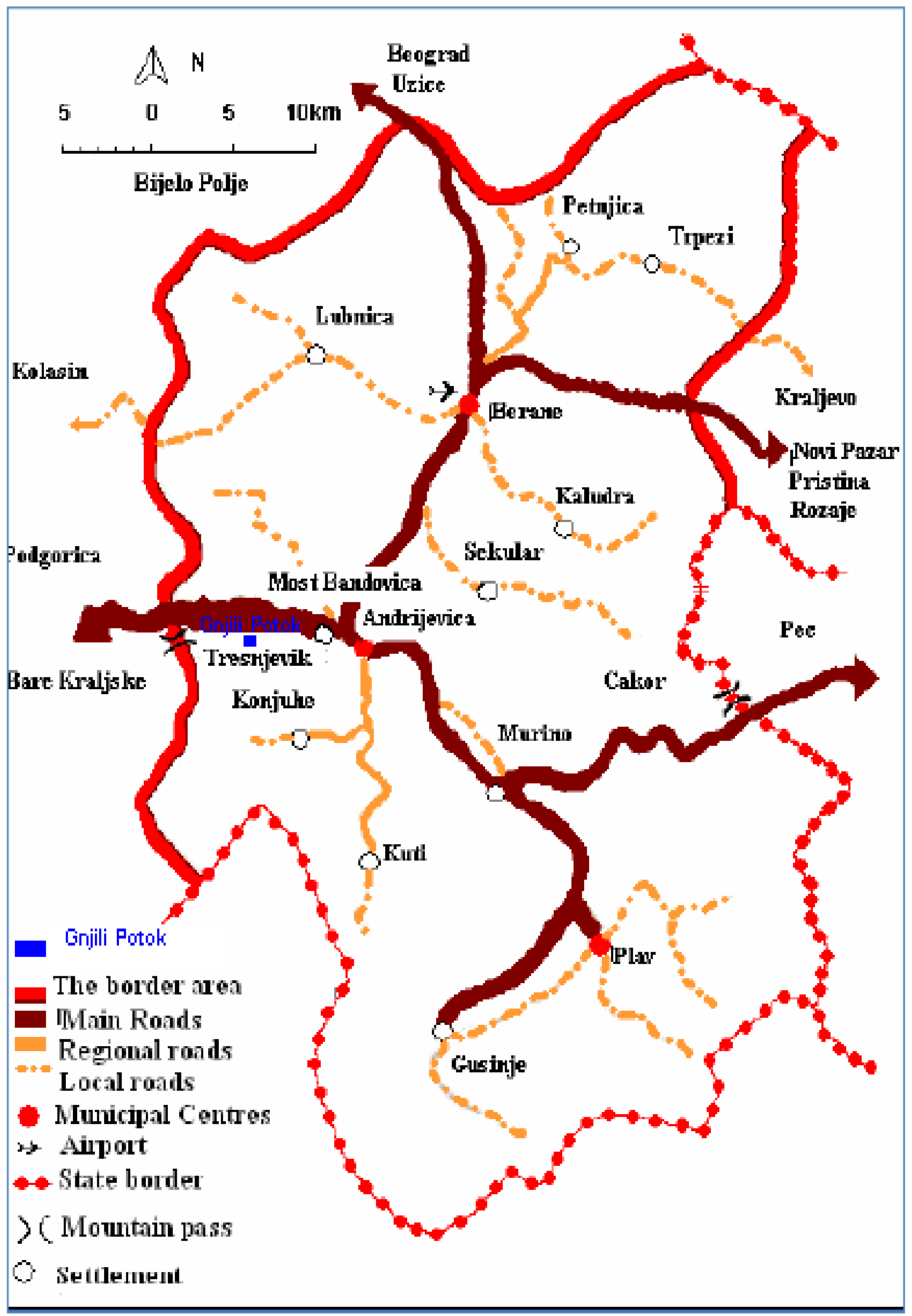

Map 1. Gnjili Potok on the map of northeastern Montenegro [6].

There are on location of Ornice and Njive Đinovića. Thus, the presence of the Illyrians in the field of Gnjili Potok speak and legends of the "the stone fox in the mountains Lisa" and the "buried gold and gold distaff on location of Radmilica".

The presence of Illyrians in the studied area, testify to the point of relief or localities, among which, on this occasion, we highlight three plateaus incurred artificial rather than natural 
manner. The first is located above the Kagina Ornice - plateau in a circular shape named Korita, the other named Rajkova Plains, the third Perinka in owned Dragoja Krstova Rajović, which is located between the Kraja and Dola Novović. It is interesting to point out that the last two plateaus have a circular shape, and both the edges of their spring water. "It appears likely that these sites were the habitat of some of the livestock of the village from the old times [3].

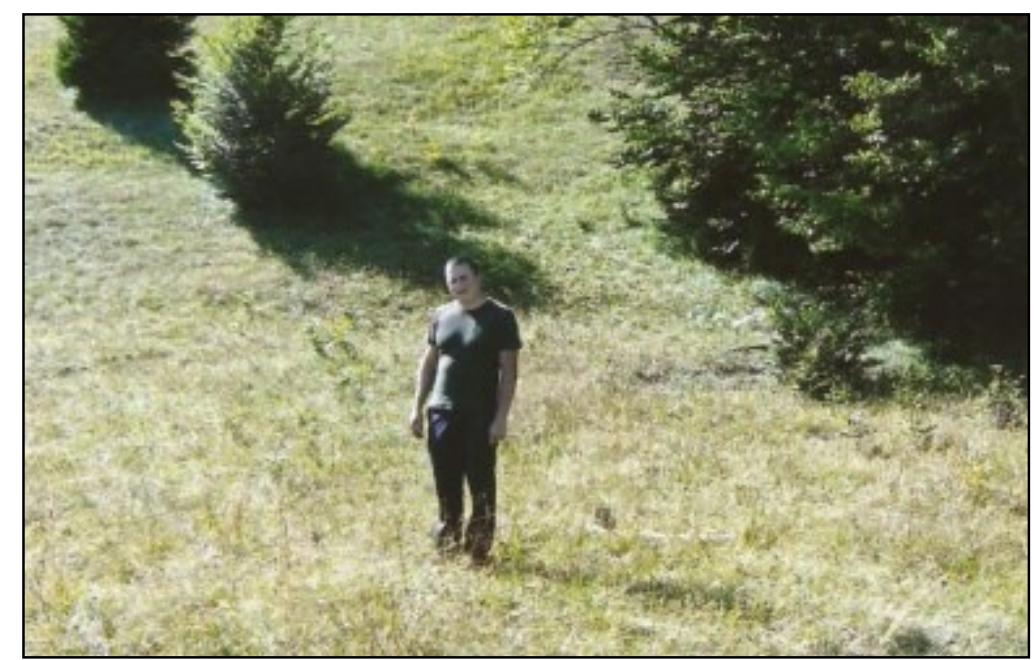

Figure 1. Perinka - are here to live ancient people? ${ }^{1}$

Historically has not been determined, but it is likely that the researched settlement penetrate the Celts that are otherwise before the arrival of the Romans, but in the fourth century, Illyrians suppressed and broad expanses. According to Blagojević [32], it is quite certain that the studied village, "as well as other parts of present-day Montenegro, the second century, was part of the Roman province and, later, the province Prevails. What are however, people they found here in the seventh century immigrant Slavic tribes - is not quite clear, but could reasonably believe that there were already Romanized Illyrians".

Since the formation of medieval Slavic countries studied village was part of Raška state, and in the late 15th century, it fell under the Turkish rule. In the Turkish time village studied was converted into an estate belonging to the Turkish leader, and its inhabitants into serf's Plavsko - Gusinjsko rulers. According to Knežević [33] the life of the serfs and the population here was difficult. Serfs were initially forced to give Turkish leaders a quarter of its annual agricultural products, and later when the Turks lost their possessions in Vasojevici on them was made even more pressure and were forced to a time and give half of their income. As they were always in conflict with the Turks, they would rather betray livestock; as farmers could almost always be removed from their movable property before the Turkish invasion. During Turkish rule the population Gnjilog Potoka is mainly engaged in extensive agriculture, because, at the time of the Turkish devastation, livestock could quickly get out of the hide and it is important for tillage. Field had a "catchall" character and satisfies there are own needs of rural households. Of debt Turkish rule, again especially it's the last centuries, filled with struggle fraternity in Gnjili Potok not only against the various shape as it were specific violence, but also for higher

\footnotetext{
${ }^{1}$ In the picture one of the authors of monographs "Natural and socio economic characteristics of rural settlements Gnjili Potok" (2010), Darko Rajović.
} 
goals definitive liberation. Final liberation of from the Turks disappearing feudal relations, possessions leader belonged to those who have dealt with them.

After the liberation wars against the Turks (1875-1878) and the Balkan Wars (1912-1913) studied the space was finally liberated of Turkish rule. A large number of villagers Gnjili Potok were mobilized for the final battle for liberation. In them perished large numbers of people and in those years many families have lost their livestock and no manpower, so that all that contributed to the impoverishment of the population. Those who have returned from the war found themselves at home even greater poverty and misery. Just a year after the end of the Balkan Wars (1912-1913), yet recovered and exhausted population of the village was forced to enter into a new - the first World War I. World War I had mobilized all the "which could to hold the rifle". In the village, next to those infirm and a woman remained feeble old men. They were not able to cultivate the land and feeding the family. Again, the large number of resident's Gnjilog Potoka participated in the most famous battles in that war. A lot of them I killed them ... They did not remain unknown or prison camps: Skadar, Elbason, Drač, Boldogarson and Nadmedzer... Those who have returned from the war found themselves at home even greater poverty and misery.

Many authors, among whom apostrophized to Vešović [34] and Dašić [35] provide a wealth of data about the neighboring rural village of the Kralje (the parent of today's of brotherhood Gnjili Potok), and on exploring the village is almost no information, except that the area served as grazing livestock breeders from the Kralje. Vešović [34] says for the king, "this is the land of kings Nemanjića ... here they were resting at the time of King Milutin when they went hunting Komove". Dašić [35] points out that the oldest written source about the Kralje, Turkish census from 1485 year, who noted the existence of 30 houses.

According to Vešović (1935) ancestor Vasojevića -Vaso, he settled with his sons Rajo, Mio and Novak on Nožica- the Lijeva Rijeka. From Vasovih sons have developed three major branches of brotherhood: Rajevići, Novakovići and Mijomanovići the five groups, of which the most powerful branch Rajević is partitioned into three parts: Lopoćane, Dabetiće and Kovačeviće. From Left Rivers, center Vasojevića, of brotherhood be displaced towards the valley of Lima, of which Dabetic inhabit the Kralje. Therefore, it appears that today's of brotherhood in rotting Potok, direct descendants Dabetini, i.e. Dabo son Raičev and grandson Raja Vasova. As a place of departure are from the Lijeva Rijeka and arriving in Kralje Vešović [34] points out Kami village.

The first mentioning of the settlement, named Gnjili Potok, found in 1744 year. Just then, the brothers Rajo and Vuka have settled in Gnjili Potok. Rajo and Vuka are born and lived at Kralja, and to Rajo at the site of today's household Jojić, a Vuka on the location of the household Blagoja Lekića. Verbal tradition indicates that after a few years in Gnjili Potok inhabiting and Labo. Thus, in the territory of Gnjili Potok began to form families Rajovih, Vukinih and Labovih descendants. Descendants of Vukin not much away from the original habitat, less than a kilometer, while the descendants of Rajovi they traveled over five kilometers, and some of them even Trešnjevik mountain pass $(1573 \mathrm{~m})$, settling in Bare Kraljske. The belt of Jelenbara and over Dubokalja at less than a kilometer from entering the territory of the village Gnjili Potok has remained in the ownership of descendants Rajovih and Vukinih, with what has been in the area Miravčina, mixing with families Martinović and Đekić. Part Arsović descendants Arsovih, remained in Miravčinama and Dubokalj, while others Arsović the Trešnjevik. Part Novović descendants Novovih, moved away from the river Čukačke the Kralje and Trešnjevik. In conclusion, the first settlers Gnjili Potok brothers Rajo and the Wolf, after a few years the descendants of today's Labović, branches Đošović and Vukotić. According Rajović [3] sons 
Rajovi (Bozo, Đole, Vukić, Milić and Cuba) and Vukin (Novo, Miloš, Radonja and Mileta) built 30 settlements in the territory studied.

For example, the descendants Vukin settled Ravna Njiva, as well as part Labovih descendants branches Vukotića and Đošović and Vujovku and the central part of the Gnjili Potok, along with Rajovim descendants, branch Milicević. At an altitude above $1100 \mathrm{~m}$ found themselves Rajovi descendants, branch Milovanovic and branches Bozović, and at an altitude of 1200 m located a few families Labovih descendants branches Vukotić. At the locality: Lanište, Krčevine, Ograđenica, Bregovi, Orničica, Rajova Rijeka are located Rajovi descendants, the branches Božovića. Locality Rajova Luka inhabits Rajovi descendant's Đolevića branches, branches Božović descendants Labovi, branches Vukotića and Rajovi descendants branches Milovanović. At the Trešnjevik are located descendants Rajovi - Arsović descendants Vukin - Novović and Labovi, branches Vukotić. At the locality Dobri Rt located descendants Labovi, branches Đošović. Locality Lugove inhabited Rajovi descendants branches Milićević. Thus, studying the territory settlements inhabited by descendants Rajovi, Vukin and Labovi. While the two families who inhabit the territory of the village Kastratović and Šekler acquired hereditary factor, i.e. purchase and sale of land.

The main relicts in the area of social life rotting Potok were tribal and family relationships. The tradition in this respect is so strong, so to say, everyone knows not only the whole range of their ancestors, to one in which the fraternity's last name, but that with which the other families and clans related by blood. Relations within the same of brotherhood were traditionally so close, to the incredible amount of respect and recognition of the relationship, of friendship. Within the family, relationships were based on authority and maximum parental respect [32]. Observes they are closeness tribesman. There is no conflict between them, their interests coincide and join together to create a new political and social relations. Changing these relationships, there is the Second World War.

According to Šljukić [36] the main objectives of the land reform after the Second World War were the ideological, political and class-social. Economic interest in agriculture was of secondary importance, and established the absolute dominance of small peasant holdings. The new socialist government has the burden of reconstruction and accelerated industrialization laid on rural areas and agriculture. Measures of forced are purchase of agricultural products and forced collectivization caused by the far-reaching negative consequences. With or difficult circumstances in the country, all of this has caused a real rustic "exodus" to the cities. While the policy of force against the peasants soon abandoned the ideological suspicion remained. Various measures (no opportunity for social and health insurance, the agricultural peak, the prohibition of procuring large agricultural machinery ...) ... Sporadic and uneven and too fast deagrarization caused the depopulation of villages ...

Population trends Gnjili Potok shows markedly decline. Number of residents in a rural village Gnjili Potok period 1948 to 2008 decreased from 325 to 81 resident or $75.1 \%$. The age structure of the number of young people from 0 to 19 in the total population was 12 , of younger adult from 20 to 39 years is 18 , older adult from 40 to 59 years is 26 , and the old 60 and above 26. Of the total population, the age group of 0 - 19 years there were 8 men and 4 women; 20 39 years 13 men and 5 women; 40 - 59 years 13 men and 13 women. Looking at the above data we see that the population of the studied area the old, and the disproportion between the male and female population affected by the increased participation of women in migration, and the girls from the village were leaving the cities and there are married.

It is interesting to point out the fact that out of 26 men (aged 20 - 59 age), a bachelor's 17. 
Extremely high number of people with no income (46), lack of population with income employees (6) pensioners (17), reflects the most economic backwardness and lack of investment in this rural village.

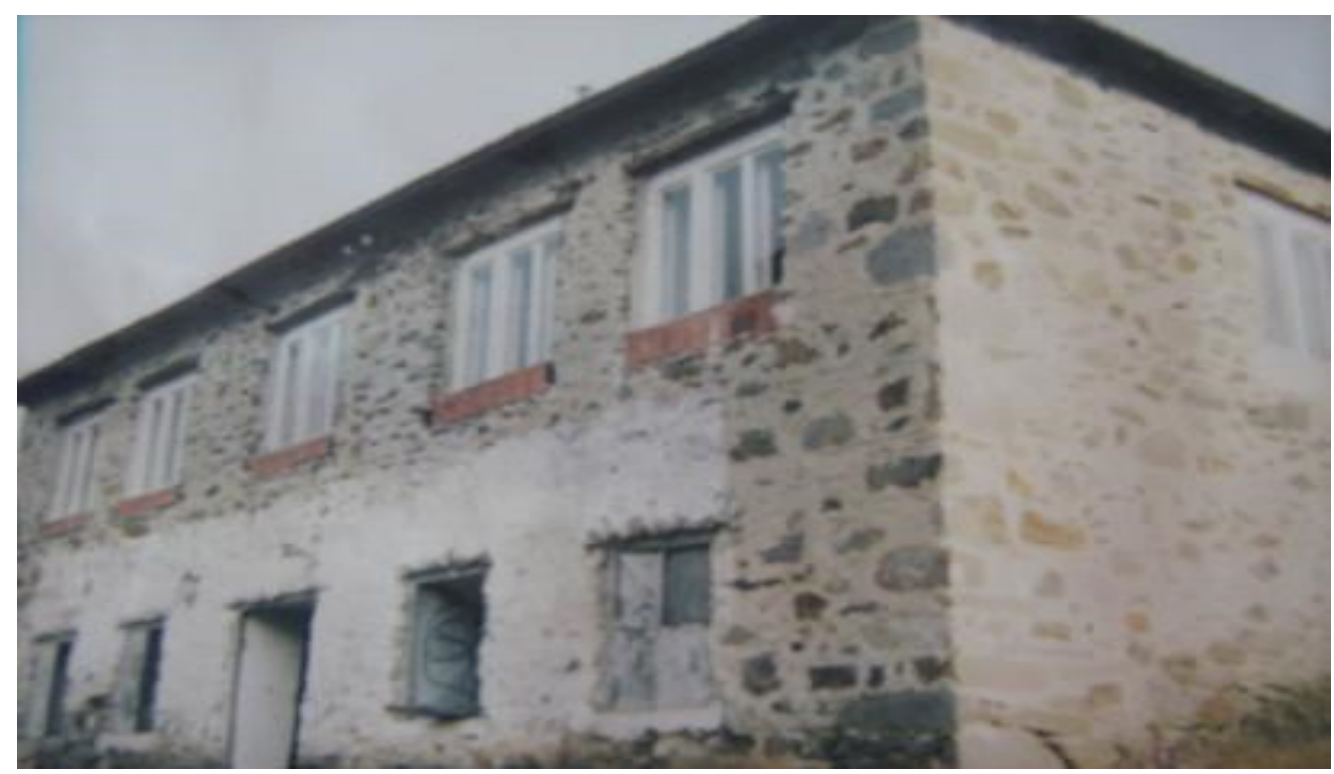

Figure 2. Basic School of rotting Potok was built in 1957- resist the ravages of time.

According to survey data to Rajović [4] in 2008, of the total population, with incomplete primary education is 35 villagers; with elementary school has 20 of them, as a result of irregular schooling. With completed secondary education are 14 people, while higher education has two inhabitants of the studied area. This qualification structure of the population, caused due to the emigration of trained in developed regions. If we add the number of children in the age group 0 to 4 years, three; 5 to 9 years two; 10 to 14 years three; 15 to 18 years four of, it is clear that this situation requires urgent socio - economic engagement.

According to statistics from 1948, the settlement the researched a total of 71 households, according to the survey data to Rajović [4] 2008 year 27 households. The fact that an average of 3.47 members of the are household who owns a farm, a very alarming from the standpoint of the development of agricultural production and application of agro-technical measures plant production. That brings us to the number agricultural holdings are: 1 member 5, 2 member 8,3 member 6, 4 member 2, 5 member 7, 6 member 1, 7 member 1, 8 member 1, while the 9 and 10 members do not have a farm.

In this period, according to Rajović and Rajović [12], reveals two modes of spatial behavior of people:

1. Traditional, which in addition to a shift towards a new social - economic relations and industrial methods of production relations remains to him in a then existing conditions does not increase the financial base on which bases its existence, and

2. Radical, which terminates the connection with the land and wants to be more incorporated into the newly formed economic - social relations. 




Figure 3. Modern house built in 2007 - Partially housing.

How is Gnjili Potok of the seventies of the twentieth century, the depopulation reached proportions that can hardly be stopped, a number of residential properties (5), and a trade (the former State general store), abandoned and left to chance and natural aging. On the other hand, there is the problem of seasonal or occasional use housing units (houses). Such is the rotten Potok 37 Accordingly, the former permanent resident's Gnjili Potok only summer or winter, come and spend a certain time in the form of vacation or partial housing.

Today, they are Montenegrin village and Montenegrin society as a whole, at the crossroads of civilization, but also in the developmental blockade. Thereby affirm clearly formulated position Šljukić [36], the action "reviving the village" cannot be a "relapse", but only a modern design aimed at all-round socio-economic, demographic, spatial, infrastructural and cultural development of the village. Village must be civilized - or it will not be. Civilized village is one that is economically, politically and culturally integrated in a global society, functionally complementary, equal status with the city.

According to the projection of EU villages characterize the possibilities of organizing a variety of production, permanent residence and housing and temporary enjoyment of the natural beauty and scenery. These are the main trends in the development of rural Europe in the future. That future of rural Europe may be a signpost for the future of rural Montenegro, if you want to be part of the civilized world. The main characteristic of rural Europe is economic diversification and expansion of secondary and tertiary services in rural areas [37].

Based on the above it can be concluded that the Montenegrin village is situated at the crossroads between failure and survival. The process of devastation of rural areas is very intense. It manifests itself in various forms. To stop the negative trends in the Montenegrin village needs a new offensive and rural development policy. Villages not only production regions, but also a place to are live, stay, rest and recreation. European experience should be a lesson to us in rural development policy, which must be adapted to local resources and initiatives [37].

On many occasions and in many studies dealing with economic revitalization and reactivation of rural settlements, stresses the need to simultaneously investing and believing in 
the possibility of renewal, really goes into a healthy market economy. By the time of writing this text, so something not only never happened, than the does not have hint of that in near future to happen [38-39].

\section{INSTEAD OF CONCLUSION}

Modern definition of "rural development" means an integrated and multi-sect oral and sustainable development of rural (non-urban) area. Sustainability is a key component of the development process in order to balance the necessity of the development of society, economy and environment, which leads to a stable and continuous development, and without the risk of endangering any element which forms an integral part of the development process. The ultimate goal is clearly defined, i.e. development path that will lead to economic, social and political change in order to improve the quality of life of the entire population of the rural area. In the case of neglecting the development of rural areas consequences for the whole country can be: non-use of the resource base and poor evaluation of existing strategic advantages for poor structural indicators of problem areas and weakening of spatial and functional integration of the territory due to depopulation significant portion of the space [40].

Strengthening EU rural development policy has become one of the main priorities of the Union. Conclusions of the European Council meeting in June 2001, in Gothenburg, expressed clearly that "the last few years, European agricultural policies give too less importance to market mechanisms, and targeted measures to support, become more oriented towards satisfying the growing demand of the public regarding food safety, food quality, product differentiation, animal welfare, environmental quality and the conservation of nature and the human environment " [41].

Following the fundamental reform of the first pillar of the Common Agricultural Policy (CAP / CAP) in 2003 and 2004, Agricultural Council in September 2005 adopted a fundamental reform of the Rural Development Policy (RR) for the period 2007 - 2013, based on a Commission proposal of 14 July 2004. Echoing the conclusions of the Conference on Rural Development in Salzburg (November 2003) and the strategic guidelines of the Lisbon and the Gothenburg European Council, which emphasize the economic, Environmental and Social Sustainability measures, outlined in the following three main objectives RR policy for the period 2007-2013:

1. Increase the competitiveness of the agricultural sector,

2. Improving the environment and rural communities through support for land management and

3. Improving the quality of life in rural areas and promoting diversification of economic activities [41].

Experiences EU indicate that the designed rural development policy, supported financially, resulting in a successful rural economy, with employment opportunities. In Montenegro, unfortunately, until now there was no consistent long-term policy for rural and only now creates a long-term strategy for rural development. All in all, it could be concluded that the Irish model of rural development can be very interesting when it comes to the rural areas of Montenegro. The Irish model of rural development to Malešević [42] was marked by the following:

1. Increasingly bigger and better organized care for rural development, understood as a process that goes beyond not only from agriculture but also on the economy in general, 
that is designed to be very active and the overall development strategy, it is a rational use of the advantages of globalization, liberalization and high mobility of transnational capital,

2. Widely activated local resources, especially human resources (which are not small, as in the rural areas live more than $40 \%$ of the population and a very favorable age structure), primarily on principles widely understood multilateral partnerships,

3. Largely restructured and (post) modernized agriculture developed general and utility infrastructure, increased size of the household (average holdings for Ireland as a whole is about $29 \mathrm{ha}$ ) and the intensive development of non-agricultural activities (especially tourism),

4. Strong attracting and rational use of heated diverse funding sources for rural development - from the structural funds of the European Union and all the more extensive direct investment in the world, to national and local funds for these purposes,

5. Highly developed institutional and non-institutional, professional and volunteer network groups, agencies, organizations, agencies, funds and centers at the national, regional, the regional and local level, involved in the creation and realization of strategies, policies and practices of rural development, structural changes in education in general, and increasing investment in this area, with the aim of continuous training for different roles in the process of integrated rural development,

6. Achieved impressive results in terms of rural development, both at local and national levels, and significantly increased individual and social standard and quality of life of people in rural areas.

Contemporary Montenegrin village is still faced with the problems that arose after the Second World War. Departure the active labor force, the transition from agricultural to nonagricultural activities, depopulation and continuous aging are just some of the problems in the country. One consequence of these processes is an increase in the number of elderly households. Aging population in the countryside becomes a special social and economic categories of people who, because of his age and poor health, facing the increasingly difficult problems [43]. The EU has failed to show how the creation of demand and economic thinking can make viable what was planned for the decline, such as villages and small producers [44-45].

When it comes to integrated rural development in Montenegro, it should be noted that we expect significant structural changes in production, organizational and management structure, in accordance with the Rural Policy of the European Union. In doing so important building of the entire network of institutions to be support integrated rural development and decentralization in rural areas of Montenegro. In fact, our country, a lot of work to all their strategies complies with international and European principles, and planned actions and activities, with priority ranking, enable the realization of the vision of rural development and its involvement in the competitive world and European trends [46].

In conclusion, the "active strategy of integrated rural development of the Republic of Ireland and almost real social movement that are effectively carries its implementation, and how these can be inspiring for us, and that in every respect. Of course that involves certain assumptions, both in terms of critical reflection on the Irish experience, so, more and more, in 
terms of creating the necessary conditions to adopt a high-quality, complex, comprehensive and viable strategy for rural development and that it is consistently and persistently carried out. That is why to us necessary to create a real social movement for integrated rural development, and to strengthen the distinctive rural culture, and self-confidence and self-consciousness, or the human dimension of our local communities

\section{References}

[1] SELOUSPELO, Development of villages in Vojvodina (2014), Available from: http://www.selouspelo.rs (04.09 2014).

[2] Rajović V., Gnjili Potok i Trešnjevik, Andrijevica: "Stupovi - Vasojevići“", 1995.

[3] Rajović V., Vrijeme i ljudi, Andrijevica:"Stupovi - Vasojevići“, 1999.

[4] Rajović G., Istraživanje i razvoj 15(32-33) (2009) 75-77.

[5] Rajović G., Gorske staze 68 (2010) 34-35.

[6] Rajović G., Bulatović J., Anuario Turismo y Sociedad 13 (2012) 171-184.

[7] Rajović G., Bulatović J., International Letters of Social and Humanistic Sciences 9 (2014) 81-99.

[8] Rajović G.,Bulatović J., International Letters of Natural Sciences 14 (2014) 59-68.

[9] Rajović G., Bulatović J., Journal of Studies in Social Sciences 2(2) (2013) 105-133.

[10] Rajović G., Bulatović J., Journal of Sustainable Development Studies 3(2) (2013) 136-167.

[11] Rajović G., Bulatović J., Journal of Social Economics Research 1(3) (2014) 20-39.

[12] Rajović G., Rajović D., Natural and socio economic characteristics of rural settlements Gnjili Potok, Belgrade: "Agencija PC Sistem", 2010.

[13] Avramović M., Naše seljačko gazdinstvo, Belgrade:Državna štapmarija,1928.

[14] Isić M., Seljaštvo u Srbiji 1918-1941, Belgrade: Institut za noviju istoriju Srbije, 2000.

[15] Hodge I., Midmore P., Économie rurale. Agricultures, alimentations, territoires 307 (2008) 23-38.

[16] Zhu F., Zhang F., Li C., Zhu T., Habitat International 41 (2014) 262-271.

[17] Liu X. Q., Bi R. T., Gao Y., Economic Geography 5 (2011) 021.

[18] Newbery R., Sauer J., Gorton M., Phillipson J., Atterton J., Environment and Planning A 45(4) (2013) 967-985.

[19] Bennett R. J., Journal of Historical Geography 38(2) (2012) 123-142.

[20] Office of Statistics Montenegro. Population census. Podgorica, 2005.

[21] Rajović G., Bulatović J., Applied Journal of Hygiene 2(3) (2013) 15-24.

[22] Gîfu D., Teodorescu M., Ionescu D., International Letters of Social and Humanistic Sciences 26 (2014) 18-28. 
[23] Novak-Marcincin J., Gîfu D., Teodorescu M., International Letters of Social and Humanistic Sciences 27 (2014) 22-33.

[24] Buşu O.V., Teodorescu M., Gîfu D., International Letters of Social and Humanistic Sciences 27 (2014) 82-93.

[25] Teodorescu M., Ionescu D., International Letters of Social and Humanistic Sciences 27 (2014) 94-99.

[26] Vlăduţescu S., Journal of Studies in Social Sciences 8(2) (2014) 333-345.

[27] Novak-Marcincin J., Gîfu D., Teodorescu M., International Letters of Social and Humanistic Sciences 29 (2014) 29- 34.

[28] Vlăduţescu S., International Letters of Social and Humanistic Sciences 29 (2014) 41-47.

[29] Borowski A., International Letters of Social and Humanistic Sciences 2 (2013) 56-60.

[30] Todorović M., Zbornik Radova Geografskog Instituta “Jovan Cvijič” SASA 57 (2007) 45-53.

[31] Đorđević P.T., Glasnik Srpskog Geografskog Društva 27 (1912) 30.

[32] Blagojević O., Bačko Dobro Polje - gorštaci u ravnici, Belgrade: Etnografski institut Srpske akademije nauka i umetnosti, 1979.

[33] Knežević M., Plavsko-Gusinjski region - Uslovi za razvoj turizma, Belgrade: Srpsko Geografsko Društvo, 1979.

[34] Vešović J.R., Pleme Vasojevića, Sarajevo: Državna štamparija, 1935.

[35] Dašić M., Vasojevići od pomena do 1860, Belgrade: Narodna knjiga, 1986.

[36] Šljukić S., Milovan M. Mitrović: Srpsko selo, Novi Sad: Matica srpska, Prikaz (1999), Available from: http://www.makroekonomija.org 2014).

[37] Gulan B., Stanje i perspektive poljoprivtrede i sela u Srbiji, Makroekonomija (2014), Available from: http://www.makroekonomija.org (03.09 2014).

[38] Rajović G., Bulatović J., Journal of Sustainable Development Studies 2(2) (2013) 229-241.

[39] Rajović G., Bulatović J., Vestnik Orel GAU 1(46) (2014) 3-13.

[40] Ruralna Mreža BiH, Šta je ruralni razvoj (2014), Available from: http://www.ruralnamreza.ba (02.09 2014).

[41] Lider + Banatski Karlovac, Poboljšanje kvaliteta života u ruralnim oblastima (2014), Available from: http://www.leader.org.rs (02.09 2014).

[42] Malešević K., Ekonomski anali 49(163) (2004) 183-202.

[43] Stanišić M., Agroekonomika (37-38) (2008) 57-66.

[44] Bulatović J., Rajović G., Zaštita prirode 61(2) (2011) 111-128.

[45] Rajović G., International Journal of Migration and Residential Mobility 1(1) (2014) 28-49. 
[46] Ristić L., Vujačić M., APEIRON 1(1) (2011).

[47] Malešević K., Kuda ide naše selo? Belgrade: IEP, 2004.

( Received 25 September 2014; accepted 04 October 2014 ) 